\title{
Notes on status and distribution of Combretum pilosum Roxb. ssp. razianum (K. G. Bhat) Chakrab. \& P. G. Diwakar
}

Sujana K. A.* and A. Pramanik

Botanical Survey of India, AJCB Indian Botanic Garden, Botanical Garden P. O., Howrah, West Bengal-711103, India.

Received: February 21, 2017; Accepted: February 28, 2017

\begin{abstract}
A critical taxonomic note provided on Combretum pilosum Roxb. ssp. razianum (K. G. Bhat) Chakrab. \& P G. Diwakar with detailed description, illustrations, distribution and conservation status.
\end{abstract}

Key words: Combretum pilosum Roxb. ssp. razianum (K. G. Bhat) Chakrab. \& P. G. Diwakar; C. razianum K. G. Bhat; Distribution; Status; Western Ghats

\section{Introduction}

As a part of investigation on rare, endemic, threatened woody climbing plants of Kerala with special interest to Western Ghats, the first author had collected specimens of an interesting species of the genus Combretum Loefling with 5 winged fruits from Aralam wildlife sanctuary in Kannur district in February 2009. After thorough study the collections were identified as Combretum razianum $\mathrm{K}$. G. Bhat, a liana endemic to Karnataka (in Dakshina Kannada). These constitute new distributional record of C. razianum in Kerala state. Subsequently, the plant is again collected in February 2011 from Kottiyoor forest range in Kannur district and in February 2014 from Peruvanamuzhi and Thamarassery-Kalpetta Ghat forests in Kozhikode district, Kerala extending the range of distribution further in southern parts of Western Ghats.

Recently, Chakrabarty \& Diwakar (2011) reduced the status of C. razianum as subspecies of Combretum pilosum Roxb. considering only the differentiating characters between the two as provided by Bhat (2005) in protologue and emphasizing possible disjunct distribution. However, in the course of present elaborated study with recently collected specimens and relevant literature it reveals that apart from the apparent differences as discussed in the protologue, C. razianum distinctly differs from Combretum pilosum as has been shown in Table 1.

Further, as regards distributional pattern, C. pilosum is widely distributed in Assam and Meghalaya of India and also found in Bangladesh, Cambodia, Laos, Myanmar, Thailand, Vietnam while the latter being endemic to Western Ghats of India found only in Karnataka and Kerala having unique habitat preference. Thus, concept of disjunct distribution does not fit well to debar distinct species status of the plant. Considering all these facts, it is proposed here to re-instate the distinct species status

\footnotetext{
*Corresponding Author:

Dr. Sujana K. A.,

Scientist D, Central Botanical Laboratory,

Botanical Survey of India,

Howrah-711103, West Bengal, India.

E-mail: sujanakole@gmail.com
}

of Combretum razianum K. G. Bhat instead treating it as a mere subspecies of Combretum pilosum Roxb.

Table 1: Major differentiating characters of C.pilosum and C.razianum

\begin{tabular}{|c|c|c|}
\hline Characters & C. pilosum & C. razianum \\
\hline Spines & Absent & Present \\
\hline Leaf Shape & Ovate to oblong & Elliptic to lanceolate \\
\hline Leaf Size & $5-15 \mathrm{~cm}$ by $2-7 \mathrm{~cm}$ & $15-25 \mathrm{~cm}$ by $4-8 \mathrm{~cm}$ \\
\hline Leaf base & Obtuse, truncate & $\begin{array}{l}\text { Rounded to subacute } \\
\text { or narrowly cordate or } \\
\text { slightly auriculate }\end{array}$ \\
\hline Mid-vein & Villosulous & $\begin{array}{l}\text { Pubescent with terete } \\
\text { glandular hairs on the } \\
\text { adaxial side }\end{array}$ \\
\hline Inflorescence & $\begin{array}{l}\text { Terminal or axillary spike, } \\
3-10 \mathrm{~cm} \text {, usually crowded } \\
\text { at branchlet apex and } \\
\text { forming a dense, leafy } \\
\text { panicle }\end{array}$ & $\begin{array}{l}\text { Large terminal panicle, } \\
\text { racemes up to } 13 \mathrm{~cm} \\
\text { long, lax inflorescence }\end{array}$ \\
\hline $\begin{array}{l}\text { Flower } \\
\text { colour }\end{array}$ & Yellow or white & Wine-red \\
\hline $\begin{array}{l}\text { Style } \\
\text { Length }\end{array}$ & $\begin{array}{l}0.8-1 \mathrm{~cm} \text {, up to the level of } \\
\text { stamens }\end{array}$ & $\begin{array}{l}1.6-1.8 \mathrm{~cm} \text {, exserted } \\
\text { in mature buds }\end{array}$ \\
\hline
\end{tabular}

Combretum razianum K. G. Bhat Indian J. Forest. 28(2):210. f.1. 2005. (Fig 1 \& 2).

Combretum pilosum Roxb.ssp. razianum (K. G. Bhat) Chakrab. \& P. G. Diwakar Indian J. Forest. 2011, 34 (4):483-484.

Type: India, Karnataka, Dakshina Kannada Dist., Puttur Taluk, Mundooru, 29 Jan 2000, K.G. Bhat 11345 (CALholo!, iso!, $\mathrm{MH}$ !, $\mathrm{K}, \mathrm{L}$ )

A large deciduous liana, 30-40 m tall. Stems up to15-30 $\mathrm{cm}$ in diameter; bark greenish brown with vertical striations, petiole modified stout spines at the base of the branchlets and on old stem, $1.5-2.5 \mathrm{~cm}$ long; branchlets brownish, terete, rusty tomentulose; hairs up to $1 \mathrm{~mm}$ long, finally glabrous. Young shoots puberulous, pinkish, turning golden brown finally green. Leaves opposite, rarely subopposite or alternate; lamina

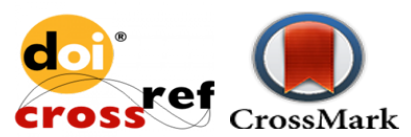


8-25 × 3-9 cm, elliptic oblong or ovate-lanceolate, chartaceous, caudate-acuminate and twisted at apex, rounded to subacute or narrowly cordate or slightly auriculate at base, margin fringed with hairs, lateral nerves 6-10 pairs, prominent beneath, sparsely pubescent above, pubescent on major nerves with small terete-capitate glandular hairs beneath; petioles 3-6 mm long, rusty tomentulose. Inflorescence axillary and terminal panicle, $75-90 \mathrm{~cm}$ long; racemes up to $13 \mathrm{~cm}$ long; peduncle thick, stout, rusty tomentulose; bracts pinkish, up to $7 \times 3 \mathrm{~mm}$, elliptic to lanceolate, pubescent. Flowers pinkish, 5-merous 2.0-2.5 ×0.8-1.2 $\mathrm{cm}$ on short pubescent pedicels $2-3 \mathrm{~mm}$ long. Calyx tube pale green, expanded portion companulate, ca. $5 \mathrm{~mm}$ long, ferruginous tomentose and villous; calyx rim dentate, lobes triangular, $8-10 \times 1-2 \mathrm{~mm}$, apex acute.
Petals pinkish, oblanceolate, villosulous, recurved, 5-6 $\times$ 2-2.5 mm. Stamens 10, filaments red, ca. $1 \mathrm{~cm}$ long; anthers yellow, suborbicular, hairy, ca. $0.5 \mathrm{~mm}$ long, dorsifixed. Ovary 4-5 × 1-1.2 mm, puberulous; style exserted in mature buds, slender, terete, pinkish red, 1.6-1.8 cm long; stigma, terete, capitate, pale white; ovules 2-3, pendulous. Fruits oblong to orbicular, pinkish, 5-winged, up to $2.5-3.5 \times 2.0-2.5 \mathrm{~cm}$; wings up to $3.5 \times 1.2 \mathrm{~cm}$, with glandular and eglandular hairs when young, glabrous when mature. Seeds solitary, fusiform $2.0-2.2 \times 0.2-0.4 \mathrm{~cm}, 5$ ridged; testa brown, membraneous.

Flowering: January - March; Fruiting: February - April.

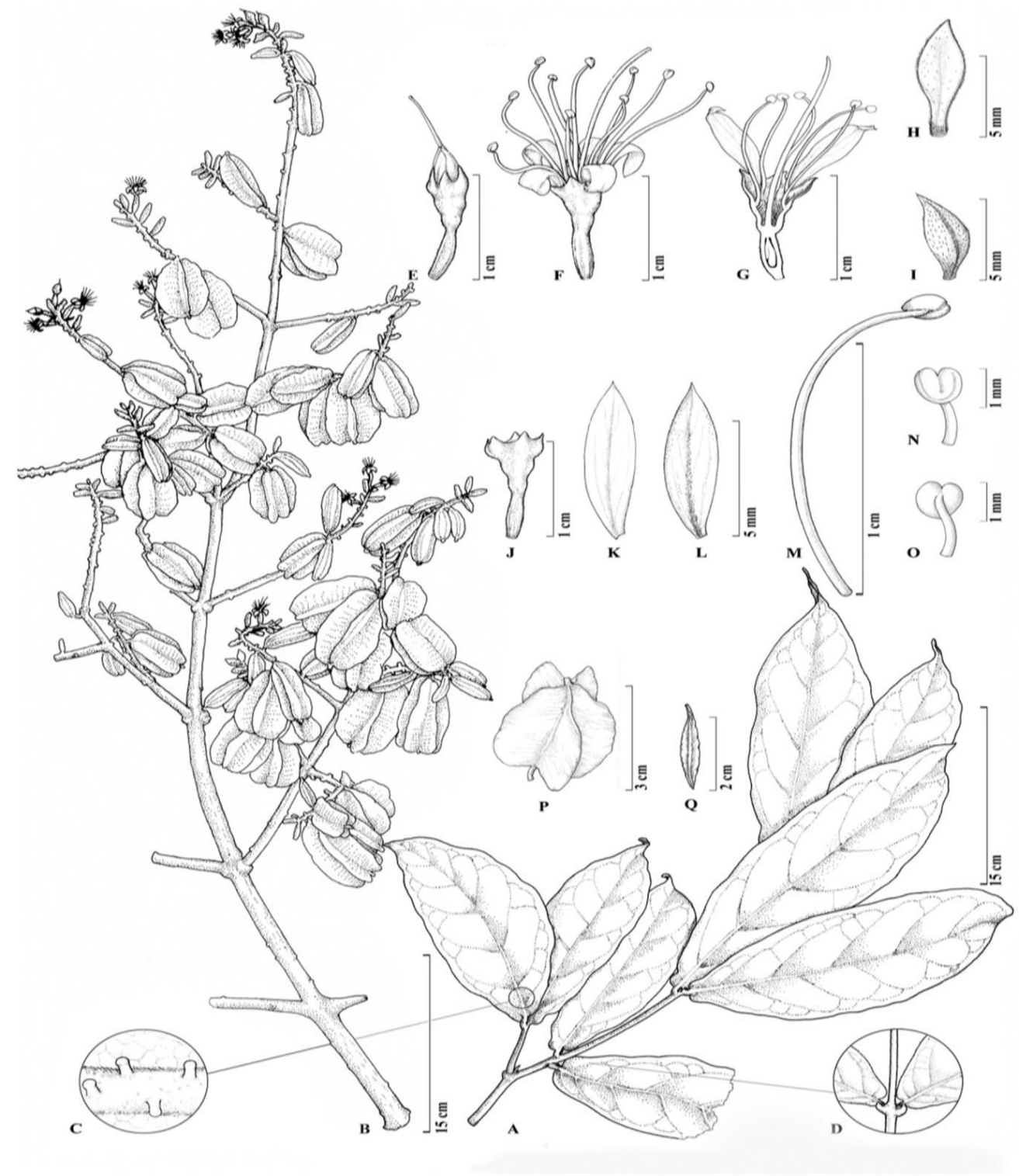

Fig. 1. Combretum razianum K. G. Bhat: A. Flowering twig; B Inflorescence; C. Portion of the adaxial mid vein with glandular appendages; D. Leaf base; E. Mature bud with exerted style; F. Flower; G.Flower - longitudinal section; H. Bract - dorsal view; I. Bract - ventral view J. Calyx tube; K. Petal - dorsal view; L. Petal - ventral view; M. Stamen; N. Anther - dorsal view; O. Anther - ventral view; P. Fruit; Q. Seed. 

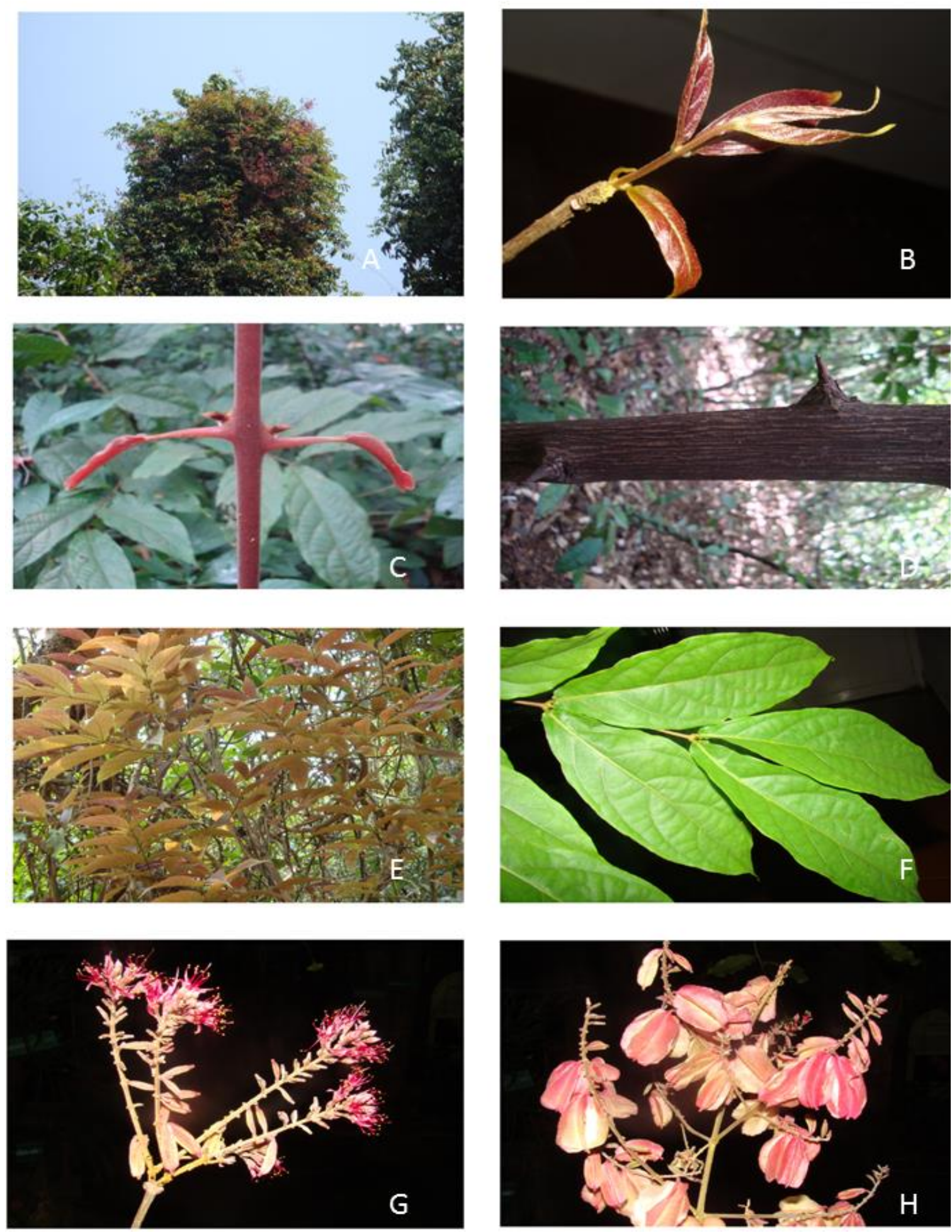

Fig. 2: Combretum razianum K. G. Bhat: A. Habit, B. Young shoot, C. Young stem, D. Spine on old stem, E. Golden brown leaves, F. mature green leaves, G. Portion of inflorescence, H. Fruiting twig

\section{Distribution:}

The plant is Endemic to Western Ghats - Karnataka: Dakhsina Kannada (Charmandy, Mundooru); Kerala: Kannur (Aralam wildlife sanctuary, Kottiyoor), Kozhikode (Peruvannamuzhi, Thamarassery-Kalpetta Ghat) (Fig. 3).
The plant is usually growing in the semi-evergreen forests of Western Ghats at an altitude ranging 40-900 m asl and is found associated with Anamirta cocculus (L.) Wight \&Arn., Baccaurea courtallensis (Wight) Müll.-Arg., Combretum latifolium Blume, Sterculia foetida L., Vateria indica L., etc. 


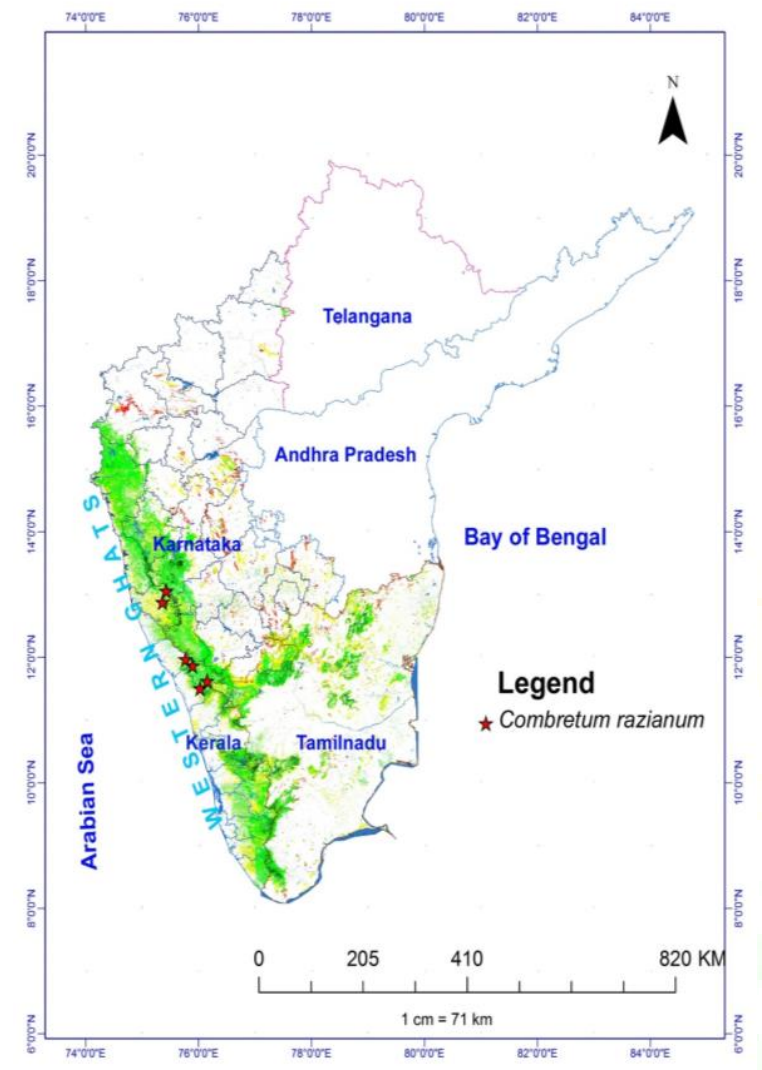

Fig. 3: Map showing distribution of Combretum razianum in India

\section{Specimens examined:}

INDIA: Kerala: Kannur - Aralam wildlife sanctuary, semi-evergreen forests, 853m, 27 February 2009, Sujana K. A. 0516; Kottiyoor, semi evergreen forests, $603 \mathrm{~m}, 03$ February 2011, Sujana K. A. 0688; Kozhikode Peruvanamuzhi, semievergreen forests, $862 \mathrm{~m}, 11$ February 2014, Sujana K. A. 0723; ThamarasseryKalpetta Ghat, semievergreen forests, $507 \mathrm{~m}, 24$ February 2014, Sujana K. A. 0731 (M.S. Swaminathan Research Foundation, CAbC, Wayanad, Kerala, India).

\section{Conservation status:}

Marati \& Shenoy (2013) noted that the regeneration of this species was very poor. This is probably due to high climbing nature and dispersal of seeds on the top of the canopy. The other reason could be because of the slope the seeds might have washed away with the onset of rains. Adopting human-assisted propagation measures and re-introduction to similar habitat may help in the conservation of this rare endemic species. This species have potential to introduce as ornamental plant.

\section{Acknowledgements}

Authors extend their sincere gratitude to Director, Botanical Survey of India, for providing all the facilities and gratefully acknowledge the logistics and supports of Forest Department, Kerala. Thanks to Mr. Manudev K. M. for illustrations and Mr. Nagaraju S. for mapping the distribution.

\section{References}

1. Bhat KG, Combretum razianum (Combretaceae), a new species from Karnataka, India. Indian J Forest, 2005, 28: 210-212.

2. Chakrabarty $\mathrm{T} \&$ Diwakar PG, A note on the status of Combretum razianum (Combretaceae). Indian J Forest, 2011, 34:483-484.

3. Marati $\mathrm{R} \&$ Shenoy $\mathrm{SH}$, Need for the conservation of Combretum razianum K.G. Bhat (Combretaceae), an Endemic Threatened Species of Western Ghats. Species, 2013, 6:16-19.

\section{Cite this article as:}

Sujana K. A. and A. Pramanik. Notes on status and distribution of Combretum pilosum Roxb. ssp. razianum (K. G. Bhat) Chakrab. \& P. G. Diwakar. Annals of Plant Sciences 6.03 (2017): 1594-1597. DOI: http://dx.doi.org/10.21746/aps.2017.03.004 